\title{
Efficiency of Banks in Pakistan: A Non Parametric Approach
}

\author{
Abdul Haque (Corresponding Author) \\ Assistant Professor at Department of Management Sciences \\ COMSATS Institute of Information Technology, Lahore, Pakistan \\ E-mail: ahaque@ciitlahore.edu.pk, ahaque_257@yahoo.com
}

Adeel Tariq

Lecturer at Department of Management Sciences

COMSATS Institute of Information Technology, Lahore, Pakistan

E-mail: atariq@ciitlahore.edu.pk, tariq.adeel@ymail.com ,

Received: April 26, 2012 Accepted: May 10, 2012 Published: June 18, 2012

doi:10.5296/ber.v2i1.1171 URL: http://dx.doi.org/10.5296/ber.v2i1.1711

\begin{abstract}
Banks play a vital role in growth and development of an economy through prudent allocation of capital resources and their efficient utilization. This study evaluates efficiency of banking sector of Pakistan, including both conventional and Islamic banking, for the time period 2006-2010 by covering a total of 22 banks; Sample includes 16 Conventional and 6 Islamic banks. Efficiency is measured through frontier non parametric technique of data envelopment analysis based on intermediation approach. During the sample period the banking sector was not much efficient in the year 2009 and the estimated efficiency scores recommend that Islamic banks performed more efficiently during the study period as compared to Conventional banks.
\end{abstract}

Keywords: Conventional Banking system, Islamic Banking System, Pakistan Banking sector, efficiency, DEA. 


\section{Introduction}

Banks have a pivotal role in growth and development of an economy where it ensures prudent allocation of capital resources and their efficient utilization; whereas it is implausible to work smoothly in modern time without a robust banking system. Recently, the developing countries have focused on performance and efficiency of banking sector given the crucial role of commercial banks as leading financial institutions. Performance evaluation of banking is significant to investors, proprietors, potential depositors and to the policy makers as banks play a major role in the formation and execution of monetary policy.

Traditionally, activities of banking sector were restricted to conventional banking (Con. Banking), but recently Islamic banking (Isl. Banking) has emerged as an alternative. Con. Banking is based on interest earnings and Isl. Banking is based on profit and loss sharing. The remarkable growth of Islamic banking in the developed and developing economies (covering 70 countries) in addition to the Muslim world contributes to its significant expansion and enhanced acceptability. Even many international conventional institutions such as Standard Chartered Bank, Citibank, HSBS, Deutsche Bank, etc, responded to this growth by establishing separate Windows and providing Islamic financial services to their customer. The main difference between both banking systems is that conventional banks are based on interest-based system, whereas the Islamic use the interest-free system and based on profit and loss sharing (PLS) principles. The four different categories used as substitute of interest based financing are; sale method financing, investment financing, rent financing and service financing. Profit and loss sharing is fundamental to Isl. banking.

Habib Bank is the only con banking institution which is working in Pakistan since independence 1947. Historically the role of banking in Pakistan was restricted to Con. Banking but later on it adopted emerging practices in the form of Isl. Banking. The first Islamic bank in Pakistan was formed in 2002 when Meezan Bank converted its operations from conventional banking to Islamic banking. According to State Bank of Pakistan (SBP) report on Islamic banking (2010), Islamic banking sector experienced phenomenal growth in the world including Pakistan since 2002. In Pakistan, Islamic banking assets are worth Rs147 billion (SBP) with market share of $12.3 \%$ in the overall banking industry and It has the largest market for ISLAMIC PRIVATE DEBT SECURITIES (IPDS). The percentage of Sukuk bonds outstanding was 56.1\% out of total outstanding bonds at 31st March 2008.

Despite significant development in the Isl. Banking, majority of the studies emphasized on profitability and size, whereas a few focused on its efficiency. Efficiency in the banking system is necessary as it accounts for number of advantages such as improved profitability, better utilization of resources, compatible prices and improved service quality and opposite relates to inefficient banks. (Berger et al. (1993a, b)). Banks efficiency can be determined using various approaches. Berger and Humphrey (1997) analyzed various studies using diverse analysis of frontier efficiency for different countries. Previously banks efficiency was measured using ratio analysis while the critics on this technique reported a number of limitations. As mentioned by Oral and Yolalan (1990) the ratio analysis does not take into account actions of the management and their investment decisions which may hamper the 
performance. Mukherjee, et al. (2002) reported that financial ratios provide an incomplete, restricted position of the process and also fail to provide interactions of the different factors, subsequently leading to contradictory results. Efficiency measurement through frontier approach is preferable over the ratios analysis as it involves various types of input and output required for function and other factors that affect the performance Iqbal and Molyneux (2005).

Farrell (1957) was the first to provide the concept of efficiency and defined it as actual results obtained are equivalent to optimal results. The two types of efficiency discussed in banking literature are Scale and X efficiency. Leibenstein (1966) first introduced the X efficiency and defined it as lowest cost of production for the given amount of output. X-efficiency is imperative as $x$-inefficiencies explain about more than $20 \%$ of the banking cost Berger, et al. (1993). The notion of the x-efficiency has two further types; technical efficiency where firm tries to obtain optimum output for the given amount of input and the allocative efficiency, where firm's inputs are utilized in optimal way. Both, the parametric and nonparametric techniques are available to execute the $\mathrm{x}$ efficiency approach to measure operational, technical and allocational efficiency. This study uses frontier non parametric technique named data envelopment analysis (DEA) to investigate $\mathrm{x}$ efficiency of overall banking sector. We further apply this technique to check the differences of efficiency of the Con. and Isl. Banks.

\section{Literature Review}

(Berger et al., 1993a, b) stated that cost efficiency was the main focus of the studies conducted to analyze efficiency. Afterward, bank's efficiency literature was flaked for not taking into account profit and revenue sides of the bank's operations. In fact, banks with higher inefficiencies and cost cannot generate higher profit as compared to efficient ones. Existing literature on efficiency of banking sector is categorized into two factions. The first faction consists of the studies that evaluate the Bank's performance using the traditional financial ratios analysis (Hassan and Bashir in 2003; Bader, Shamsher and Taufiq in 2007). The second faction of studies centers on efficiency of banks and utilize the frontier analysis technique rather than applying the ratio analysis: literature that analyze the efficiency of the conventional banks (Weill in, 2004; Bos and Kool in 2006; Bader in 2007); literature that analyze Islamic Banks efficiency (Brown and Skully in 2005; Bader, Ariff and Taufiq in 2007a). A few interesting studies attempted to make a comparative study between Con. and Isl. banks (Bader, Shamsher and Taufiq in 2007; Bader, Shamsher, Ariff and Taufiq in 2007).

Hassan et al (2009) examined various kinds of efficiency of banking system of 11 OIC countries from the period 1990-2005 using DEA analysis. No differences were found in efficiency of the Con. and Isl. Banks. Studies conducted to calculate the efficiency of banking sector on developing countries are by Banker et al. in (2010) in South Korea, Chiu and Chen in Taiwan (2009) and Hsiao et al. in (2010) Taiwan and Heffernan in (2007) and Haw et al. in (2010) South Korea, Indonesia, Thailand, Philippines, Malaysia and Taiwan and Lozano and Pasiouras in (2010)._Sun and Chang (2011) investigated the influence of risk adopted methods on banks efficiency in developing countries of Asian region and reported that risk 
measures have significant positive influence on bank's efficiency and it varies in different countries during different time periods. In developed countries, researchers dedicated more efforts in investigating conventional banking system only, whereas studies related to Isl. Banking are more related to the developing countries.

Given afore-mentioned facts, we hardly find a single study examining the efficiency of banking system of Pakistan whether Con. or Isl. or both at international level; although few country level studies are available discussing only profitability and size of the banking sector. Akhtar (2002) analyzed the X and overall efficiency of Con. Banks only from 1998-99 by using the DEA approach. His study covered only two years' time period and did not include Isl. Banks in the sample. Attaullah et al. (2004) analyzed the effects of privatization on Pakistani and Indian banks by measuring the scale, technical, overall technical efficiency for the time period of 1988-1998 and reported that banking system of Pakistan has experienced improved efficiency after privatization. Recently Khalid (2006) examined the effects of privatization on the Pakistani conventional banks only for the time period 1990-2002. This paper adds to the literature by investigating the efficiency of overall, Con. and Isl. Banks in Pakistan for the period 2006-2010,_utilization of recent data and non-parametric econometric technique adds to its significance. The next section provides the detail about methodology used in this study.

\section{Methodology}

\subsection{Data Envelopment Analysis}

This paper applies DEA to analyze the $\mathrm{x}$ efficiency of the Pakistani banking sector. DEA assumes that all underlying units use the similar amount of technology to make output by using the available input. In DEA, efficiency in production is determined by using Decision Making Units (DMUs) which help examiner to identify the best performing unit and to compare its performance with other units. This technique enables the evaluator to use multiple outputs and inputs. Under this technique the score assigned to DMUs range from 0 to 1 , whereas the 1 is given to the most efficient. It is not necessary to gain score of 1 for best practicing or most efficient unit or to give maximum output. A best Decision making unit is one which provides maximum output from given set of input. Hence DEA is a preferred technique for measuring efficiency even dealing with small sample size (Isik and Hassan, 2002 and Ataullah et al., in 2004).

Two ways to select inputs and outputs to measure bank's efficiency are; operating and intermediating approach. In first approach bank is considered to be provider and producer of different services for its clients and is evaluated form cost/revenue administration perspective. The intermediation method is given by, Sealey and Lindley (1977), which completes the operating approach. In second approach bank is considered to be an intermediary of financial services and convert these resources into loans and other assets. This method provides various benefits as compared to production approach for analyzing financial institutions as it includes interest and/or funding expenses.

\subsection{Empirical Model}




\section{IIMacrothink}

Many DEA models have been used to measure the efficiency. Widely used models are developed by Charnes, Cooper and Rhoades (CCR) model of Charnes et al. (1978) and Banker, Charnes and Cooper (BCC) model of Banker et al. (1984). CCR takes the firm or DMUs as function of CRS (constant return to scale) whereas BCC extends the model to variable return to scale.

Efficiency of banks is calculated as follow:

$$
e_{s}=\sum_{i=1}^{m} u_{i} y_{i s} / \sum v_{j} x_{j s}, \text { for } i=1, \ldots . ., m \text { and } j=1, \ldots ., n
$$

Yis indicates the ith output amount generated by sth bank, xjs indicates $j$ th input amount applied by the sth bank, $u i$ is weight of the output, $v j$ is weight of the input. The ratio used to select the optimal weights is:

$$
\sum_{i=1}^{m} u_{i} y_{i s} / \sum v_{j} x_{j s} \leq 1, \text { for } r=1, \ldots \ldots, N \text { and } u_{i} \text { and } v_{j} \geq 0
$$

Equation (1) ensures efficiency ratio to be at least one and the equation (2) ensures that weights are positive.

Above fractional equations can be converted into linear equations as:

$$
\begin{aligned}
& \max \text { imize } e_{s}=\sum_{i=1}^{m} u_{i} y_{i s} \\
& \text { subject to } \sum_{i=1}^{m} u_{i} y_{i s}-\sum_{j=1}^{m} v_{j} x_{i r} \leq 0, r=1, \ldots \ldots \ldots . . N ; \\
& \sum_{j=1}^{m} v_{j} x_{i r}=1 \text { and } u_{i} \text { and } v_{j} \geq 0 .
\end{aligned}
$$

Likewise, it can be transformed into the dual problem as:

$$
\begin{aligned}
& \text { min imise } \xi_{s} \\
& \text { subject to } \sum_{r=1}^{N} \varphi_{r} y_{i r} \geq y_{i s}, i=1, \ldots \ldots ., m ; \\
& \xi_{s} x_{j s}-\sum_{r=1}^{N} \varphi_{r} x_{i r} \geq 0, j=1, \ldots \ldots . ., n ; \varphi_{r} \geq 0, \\
& \text { and } 0 \leq \xi_{s} \leq 1,
\end{aligned}
$$


Where $\xi_{s}$ indicates the sth bank total technical efficiency. The linear programming equations (3) and (4) assume CRS.

\subsection{Specification of Inputs and Outputs}

As Isl. banks follow equity based capital structure, so this paper used intermediation approach to determine efficiency with 3 outputs and 3 inputs.

\subsubsection{Output}

$\mathrm{X}_{1:}$ Investment and Financing

$\mathrm{X}_{2}$ : Total Income

$\mathrm{X}_{3}$ : Liquid Assets

\subsubsection{Input}

$$
\begin{aligned}
& \mathrm{y}_{1}: \text { Administrative Costs } \\
& \mathrm{y}_{2}: \text { Operating Fixed Assets } \\
& \mathrm{y}_{3}: \text { Total Deposits }
\end{aligned}
$$

\subsubsection{Sample}

Commercial banks are used in the study to conduct analysis. Only those banks are selected for which data is available for the period 2006-2010. Following this criterion only 16 Con. Banks and 6 Isl. Banks are selected. Data is extracted from the financial statements published at website of the State Bank of Pakistan and the banks' websites. All the amounts used for inputs and outputs are in Pakistani rupees.

\section{Estimations:}

\subsection{Descriptive Statistics:}

Table 1

\begin{tabular}{|l|l|l|l|l|l|l|l|}
\hline \multicolumn{7}{|l|}{ Descriptive Statistics (in Mn) } \\
\hline \multicolumn{1}{|c|}{} & \multicolumn{7}{|c|}{ ) } \\
\hline Variables & Min. & Mean & Median & Max. & SD & Skew. & Kurt. \\
\hline Fixed Assets & 71.418 & 7167.328 & 3002.45 & 102134 & 11853.37 & 5.277 & 40.714 \\
\hline Staff Cost & 145.526 & 4961.336 & 2623.991 & 24252.96 & 5368.066 & 1.578 & 4.942 \\
\hline Deposits & 288.762 & 158523.9 & 99169.38 & 1003331 & 183090.1 & 1.866 & 7.169 \\
\hline Total Income & 17.334 & 19516.84 & 11478.92 & 147384.5 & 23412.44 & 2.267 & 10.565 \\
\hline Loan and Advances & 10.776 & 151070.6 & 96994 & 714659.1 & 164700.7 & 1.365 & 4.271 \\
\hline Liquid Assets & 924.691 & 28526.95 & 17658.59 & 149392.8 & 30110.68 & 1.513 & 5.036 \\
\hline
\end{tabular}

Table 1 provides descriptive statistics of variables used in the study for 22 banks over the sample period 2006-2010. Fixed assets, staff cost and deposits are inputs while total income, 
loans \& advances and liquid assets are outputs. Values of both inputs and outputs are measured in million rupees. Minimum, maximum Mean, median, standard deviation, skewnes and kurtosis are calculated. The staff cost has a minimum mean value while deposits have the highest standard deviation among all the included variables. Fixed asset has the highest skewnes among all the variables with the maximum value of kurtosis; these high values indicate a continuous rise in the size and volume of the fixed assets. As the banks attract lesser loans and advances at outset of its business and are subject to increase with the time period which cause a high SD in the overall time period and the same phenomenon is reflected in the reported descriptives.

\subsection{Estimated Results of DEA:}

Table 2. Efficiency score of All Banks

\begin{tabular}{|c|c|c|c|}
\hline SR No. & Year & CRS & VRS \\
\hline 1 & Allied Bank & 0.776 & 0.923 \\
\hline 2 & Askari Bank & 1 & 1 \\
\hline 3 & Bank Alfalah & 0.718 & 0.911 \\
\hline 4 & MCB Bank Limited & 0.861 & 1 \\
\hline 5 & NIB Bank & 0.953 & 0.968 \\
\hline 6 & UBL & 0.808 & 1 \\
\hline 7 & Bank Al Habib & 0.795 & 0.797 \\
\hline 8 & Habib metro politon Bank & 1 & 1 \\
\hline 9 & Standard Chartered bank & 0.88 & 1 \\
\hline 10 & Soneri Bank & 0.840 & 0.844 \\
\hline 11 & Faysal bank & 0.807 & 0.812 \\
\hline 12 & Silk Bank & 1 & 1 \\
\hline 13 & JS Bank & 0.798 & 0.821 \\
\hline 14 & KASB Bank & 0.773 & 0.776 \\
\hline 15 & Habib Bank ltd. & 0.778 & 1 \\
\hline 16 & Atlas Bank & 0.689 & 0.696 \\
\hline 17 & Meezan Bank & 0.659 & 1 \\
\hline 18 & Bank Islami & 0.679 & 0.686 \\
\hline 19 & Dubai Islamic Bank & 0.756 & 0.756 \\
\hline 20 & Dawood Islamic Bank & 1 & 1 \\
\hline 21 & Albaraka Islamic Bank & 1 & 1 \\
\hline 22 & $\begin{array}{l}\text { Emirates global islamic } \\
\text { bank }\end{array}$ & 0.755 & 0.7609 \\
\hline
\end{tabular}

Table 2 shows the efficiency scores of all banks included in the sample. It is clear from table 2 that banks show different efficiency scores (CRS) over time period, with Askari, Habib metro Politon, Silk, Dawood and Al Barka bank are most efficient as they get the score of 1 on scale. Meezan bank shows Minimum efficiency score of 0.659 in the sample. In our sample Isl. Banks comprise of $28 \%$ of it while Con. banks comprises much greater portion of 
the sample i.e. $72 \%$ of the sample. The efficiency scores recommend 5 banks as most efficient as they have a score of 1, out of which 2 are Isl. Banks and 3 are Con. Banks. In Con. Banking Atlas Bank shows minimum efficiency on scale because it is a captive bank. It has lesser number of branches and financing facilities for consumer as compared to its counterpart bank.

4.3 Efficiency Score of Overall Con. And Isl. Banks from 2006 to 2010.

Table 3.

\begin{tabular}{|l|l|l|l|}
\hline SR No. & Year & CRS & VRS \\
\hline Con. Banks & 2006 & 1 & 1 \\
\hline Con. Banks & 2007 & 0.985 & 1 \\
\hline Con. Banks & 2008 & 0.922 & 0.94 \\
\hline Con. Banks & 2009 & 0.599 & 0.884 \\
\hline Con. Banks & 2010 & 0.868 & 0.867 \\
\hline Isl. Banks & 2006 & 1 & 1 \\
\hline Isl. Banks & 2007 & 0.983 & 0.988 \\
\hline Isl. Banks & 2008 & 0.921 & 1 \\
\hline Isl. Banks & 2009 & 1 & 1 \\
\hline Isl. Banks & 2010 & 0.979 & 1 \\
\hline
\end{tabular}

Table 3 provides the efficiency results for Con. and Isl. Banks. Con. Banks demonstrated enhanced efficiency in the year 2006 due to overall improved economic conditions in Pakistan. While efficiency score declined in 2007 onwards due to global financial crunch. Given the deteriorating economic conditions in 2009 Con. Banks were least efficient with the efficiency score of 0.599. The fluctuating/falling efficiency score of the Con. Banks in the year 2007, 2008, 2009 and 2010 provided a terrific opportunity to the Isl. Banks to gain the investor confidence and gained an efficiency score equal to that of Con. Bank and even higher efficiency score in the year 2009 and 2010. There is a recent shift in the market as the efficiency scores of Con. Bank are 0.599 and 0.86 for year 2009 and 2010 respectively while the Islamic Banks had an efficiency score of 1 and 0.979 respectively for the said years. Fundamental difference in the capital structure of Con. Banking and Isl. Banking system makes the earlier one more prone to the financial or economic conditions (as is obvious from the CRS scores of Con. Banks) 1, 0.98, 0.922, 0.599 and .868. Out of all estimated efficiency scores over the sample period for both Con. and Isl. Banks the least efficiency score of 0.599 appears for the Con. Banks and it is in the year 2009. The table 3 also provides the efficiency score for both types of banks by using the VRS. The facts observed by using the CRS are also verified further by using the VRS.

4.4 Efficiency Score of All Commercial Banks from 2006 to 2010.

Table 4. 


\begin{tabular}{|l|l|l|l|}
\hline SR No. & Year & CRS & VRS \\
\hline 1 & 2006 & 1 & 1 \\
\hline 2 & 2007 & 0.811 & 0.859 \\
\hline 3 & 2008 & 0.734 & 0.774 \\
\hline 4 & 2009 & 0.732 & 1 \\
\hline 5 & 2010 & 1 & 1 \\
\hline
\end{tabular}

Finally the table 4 provides the overall efficiency scores of banking sector for the year 2006 to 2010. The banks have the highest efficiency score of 1 by using both CRS and VRS in Year 2006 and 2010. The minimum efficiency score of 0.732 is observed for the year 2009. This least efficient score is attributed to poor performance of Con. Banks in the same year which not only affected the performance of Con. Banks but in addition resulted in a reduced overall banking efficiency. The banks obtained an efficiency score of 1 in the year 2010 but because of the highest efficiency score of the Isl. banks rather than the Con. banks. The findings of this table lend further support to the idea that the Isl. banks are contributing positively and significantly to the overall efficiency of banking sector.

Our findings are reported by using CRS and VRS efficiency scores over the sample of 22 banks and for the year 2006 to 2010. The other studies, using the different estimation techniques, banks and time period must be interpreted carefully and should not be confused with ours.

\section{Conclusion}

This empirical study highlights the efficiency of individual banks, Con. \& Isl. Banks and overall banking system of Pakistan over the sample period 2006 to 2010. The study included a sample of 22 banks covering both the Con. and Isl. banks operating in Pakistan. The efficiency scores were estimated through Data envelopment analysis (DEA) by using the CRS and VRS. The descriptive statistics of 6 variables (inputs and outputs) included in the study revealed that fixed assets (Variable) has the highest skewnes and kurtosis while the deposits have the highest standard deviation. The efficiency scores of the individual banks declared the five banks to be the most efficient with the score of 1over the sample time period from 2006 to 2010 and among them three were the Con. and 2 were the Isl. Banks. While the efficiency scores obtained for the Con. and Isl. banks highlight the two important facts. Firstly, the falling and deteriorating efficiency score of Con. banks, secondly, the consistent and improving efficiency of Isl. Banks over the year 2006 to 2010. Finally, the overall banking performance in Pakistan seems to be deteriorating from 2006 to 2009 with the efficiency score falling from 1 to 0.732 . Even at the verge of this falling performance the Isl. Banks had a positive contribution whereas the Con. Banks caused the deteriorating efficiency scores.

\section{References}

Akhtar, M. A. (2002). X-Efficiency Analysis of Commercial Banks in Pakistan: A Preliminary Investigation. The Pakistan Development Review. 41. 567-580. www.pide.org.pk/pdf/PDR/2002/Volume4/567-580.pdf. 
Ataullah, A. T. Cockerill, H. L. (2004). Financial Liberalization and Bank Efficiency: A Comparative Analysis of India and Pakistan. Applied Economics. 36. 1915-1924. www.tandfonline.com/doi/abs/10.1080/000368404200068638

Banker, R. D. Charnes, A. Cooper, W. W. (1984). Some Models for Estimation Technical and Scale Inefficiencies in Data Envelopment Analysis. Management Sciences. 30. 1078-1092. www.jstor.org/stable/10.2307/2631725.

Banker, R. D. Chang, H. Lee, S. Y. (2010). Differential impact of Korean banking system reforms on bank productivity. Journal of Banking and Finance. 34. 1450-1460. http://www.sciencedirect.com/science/article/pii/S0378426610000932.

Bader, M. K. (2007). Cost revenue and profit efficiency of conventional banks: Evidence from nineteen developing countries, In Capital Markets in Emerging Markets: Malaysia, ed. 15, 2. www.ses.ac.ir/...banking.

Bader, M. K. Ariff, M. Taufiq, H. (2007). Efficiency of Islamic banks: International evidence, Paper presented in the 14th Annual Global Finance Conference GFC. April 1-4, 2007 in Melbourne, Australia.

Berger, A. N. Hunter, W. C. Timme, S. G. (1993). The efficiency of financial institutions: A review and preview of research past, present and future. Journal of Banking and Finance. 17. 221-249. www.sciencedirect.com/science/article/pii/037842669390030H.

Berger, A. N. Hancock, D. Humphrey, D. B. (1993). Banking efficiency derived from the profit function. Journal of Banking and Finance. 17 (2-3). 317-347. www.sciencedirect.com/science/article/pii/037842669390035C.

Berger, A. N. Humphrey, D. B. (1997). Efficiency of financial institutions: International survey and directions for future research. European Journal of Operational Research. 98. 175-212. papers.ssrn.com/sol3/papers.cfm?abstract_id=8410.

Bos, J. W. B. Kool, C. J. M. (2006). Bank efficiency: The role of bank strategy and local market conditions. Journal of Banking and Finance. 30. 1953-1974. www.sciencedirect.com/science/article/pii/S037842660500155X.

Brown, K. Skully, M. (2005). Islamic banks: A cross-country study of cost efficiency performance, Accounting, Commerce \& Finance. The Islamic Perspective Journal. 8. 43-79.

Chiu, Y. H. Chen, Y. C. (2009). The analysis of Taiwanese bank efficiency: incorporating both external environment risk and internal risk. Economic Modelling. 26. 456-463. wWw.sciencedirect.com/science/article/pii/S0264999308001259

Charnes, A. Cooper, W. W. Rhodes, E. (1978). Measuring Efficiency of Decision Making Units. European Journal of Operational Research. $2.29-44$. www.vwl.tuwien.ac.at/hanappi/Lehre/MSM2010/Charnes_1978.pdf

Farrell, M. J. (1957). The Measurement of Productive Efficiency. Journal of the Royal Statistical Society. 120. 253-81. www.lib.ctgu.edu.cn:8080/wxcd/qw/285.pdf 


\section{Macrothink}

Business and Economic Research ISSN 2162-4860 2012, Vol. 2, No. 1

Fu, X. Heffernan, S. (2007). Cost X-efficiency in China's banking sector. China Economic Review. 18. 35-53. www.journals.elsevier.com/china-economic-review/

Hsiao, H. C. Chang, H. Cianci, A. M. Huang, L. H. (2010). First financial restructuring and operating efficiency: evidence from Taiwanese commercial banks. Journal of Banking and Finance. 34. 1461-1471. econpapers.repec.org/RePEc:eee:jbfina.

Haw, I. M. Ho, S. S. M. Hu, B. Wu, D. (2010). Concentrated control, institutions, and banking sector: an international study. Journal of Banking and Finance. 34. 485- 497. linkinghub.elsevier.com/retrieve/pii/S0378426609002052.

Hassan, M. K. Bashir, A. M. (2003). Determinants of Islamic banking profitability. ERF paper. nzibo.com/IB2/Determinants.pdf.

Iqbal, M. Molyneux, P. (2005). Thirty years of Islamic banking: History, performance, and prospects. New York: Palgrave Macmillan. islamiccenter.kau.edu.sa/arabic/Magallah/Pdf/.../191-BReveiw_11.

Isik, I. Hassan, M. K. (2002). Cost and profit efficiency of the Turkish banking industry: An empirical investigation. The Financial Review. 37. 257-280. onlinelibrary.wiley.com.

Khalid, U. (2006). The Effect of Privatization and Liberalization on Banking Sector Performance in Pakistan. SBP Research Bulletin. 2. 403-425. www.sbp.org.pk.

Leibenstein, H. (1966). Allocative Efficiency Vs' X-Efficiency. American Economic Review. 56. 392-415. msuweb.montclair.edu/ lebelp/LeibensteinXEffAER1966.pdf

Lozano-Vivas, A. Pasiouras, F. (2010). The impact of non-traditional activities on the estimation of bank efficiency: international evidence. Journal of Banking and Finance. 34. 1436-1449. www.sciencedirect.com/science/article/pii/S0378426610000154

Mukherjee, A. Nath, P. Pal, M. N. (2002). Performance Benchmarking and Strategic Homogeneity of Indian Banks. International Journal of Bank Marketing. 20. 122-39. www.emeraldinsight.com/journals.htm?articleid $=855058$.

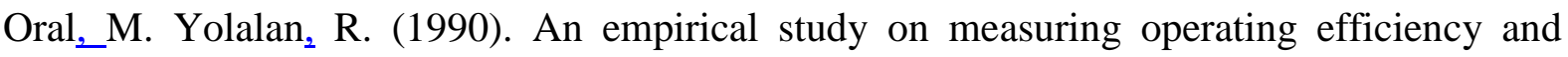
profitability of bank branches. European Journal of Operational Research. 46. 282-294. www.sciencedirect.com/science/article/pii/037722179090002S

Sealey, C. W. Lindley, J. T. (1977). Inputs, outputs, and theory of production cost at depository financial institutions. Journal of Finance. 32. 1251-1266. www.jstor.org/stable/10.2307/2326527.

Sun, 1. Chang, T. P. (2011). A comprehensive analysis of the effects of risk measures on bank efficiency: Evidence from emerging Asian countries. Journal of Banking \& Finance. 35. 1727-1735.

Weill, L. (2004). Measuring cost efficiency in European banking: A comparison of frontier techniques. Journal of Productivity Analysis. $21 . \quad 133-152$. http://www.springerlink.com/content/138461033n412126. 


\section{Copyright Disclaimer}

Copyright reserved by the author(s).

This article is an open-access article distributed under the terms and conditions of the Creative Commons Attribution license (http://creativecommons.org/licenses/by/3.0/). 